\title{
COMPARISON OF PROCTOR AND UNIAXIAL COMPRESSION TESTS FOR SELECTED SOILS
}

\author{
Dariusz Błażejczak ${ }^{*}$, Kinga Śnieg, Małgorzata Słowik
}

Department of Construction and Usage of Technical Devices, West Pomeranian University of Technology in Szczecin

${ }^{*}$ Corresponding author: e-mail: dariusz.blazejczak@zut.edu.pl

\begin{tabular}{|c|c|}
\hline ARTICLE INFO & ABSTRACT \\
\hline $\begin{array}{l}\text { Article history: } \\
\text { Received: January } 2018 \\
\text { Received in the revised form: } \\
\text { January } 2018 \\
\text { Accepted: February } 2018 \\
\end{array}$ & \multirow{2}{*}{$\begin{array}{l}\text { The objective of this paper was to compare the results of soil material } \\
\text { compaction carried out with the use of the Proctor and uniaxial com- } \\
\text { pression tests in order to find relations between these methods. Soil } \\
\text { material in the form of loose mass was collected from the layer depos- } \\
\text { ited at the depth from } 35 \text { to } 60 \mathrm{~cm} \text { in order to determine its typical } \\
\text { properties (textural group, density of solid particles, humus content, } \\
\text { reaction, plastic and liquid limits) and in order to compact it in the } \\
\text { Proctor apparatus and in the uniaxial compression test. Results of both } \\
\text { tests were used for construction of regression models reflecting the } \\
\text { course of the unit stress }\left(P_{\rho d p}\right) \text {, necessary to generate compaction equal } \\
\text { to the dry density of solid particles obtained in the Proctor apparatus } \\
\left.\left.\text { ( } \rho_{\mathrm{dp}}\right) \text { in relation to the sample moisture ( } w_{\mathrm{s}}\right) \text {. It was stated that the } \\
\text { stress value } P_{\rho d p} \text { on the soil sample in the uniaxial compression test } \\
\text { depends significantly on } w_{\mathrm{s}} \text {. It was proved that for the purpose of com- } \\
\text { paring the results of both tests, the uniaxial stress of samples must be } \\
\text { performed in conditions of their lateral expansion. It was also proved } \\
\text { that the use of the uniaxial test with possible lateral expansion of soil } \\
\text { with a model sample, a diameter of which is } 100 \text { and the height is } 30 \\
\text { mm, one may determine the obtained compaction with the use of the } \\
\text { plate movement value. }\end{array}$} \\
\hline $\begin{array}{l}\text { Key words: } \\
\text { soil, } \\
\text { compaction, } \\
\text { Proctor test, } \\
\text { uniaxial test }\end{array}$ & \\
\hline
\end{tabular}

\section{Introduction}

Excessive soil compaction which results from the impact of wheels of agricultural machines and vehicles is one of the most serious problems of modern agriculture (van den Akker et al., 2003). Soils which are particularly susceptible to compaction are as follows: heavy clays, clays, and sandy loams (Krasowicz et al., 2011). Excessive compaction of subsoil is mainly dangerous because the effects of compaction of this layer are long-lasting and its liquidation through deep loosening is energy consuming and often ineffective (Szeptycki, 2003). A rational approach to counteracting this phenomenon requires evaluation of the present soil density and identification of conditions in which it takes place.

Dry density of solid particles is popular in the density tests. Direct use of results of measurements of dry density of solid particles in the context of its influence on the plant growth conditions causes many problems (Błażejczak and Dawidowski, 2013). These diffi- 
culties cause that there are attempts to use relevant measures of soil compaction as an indicator of evaluation of plant growth conditions (Hakansson and Lipiec, 2000).

On the other hand, identification of conditions, in which the risk of excessive soil compaction raises considerably, consists mainly in determination of the soil moisture value at which its maximum compaction is possible. Parameters which, on one hand, may constitute the reference point in evaluation of the soil compaction conditions and on the other hand, describe the conditions of the maximum susceptibility on its compaction, are results of research obtained with the Proctor apparatus in the form of the maximum density and optimal compaction moisture (Wagner et al., 1994, Aragón et al., 2000; Nhantumbo and Cambule 2006; Tarkiewicz and Nosalewicz, 2005). The maximum value of dry density ( $\rho d s)$ obtained in the standard Proctor method is considered as the maximum possible to be obtained for particular soil (Kumar et al., 2009).

From the point of view of counteracting the excessive soil compaction, the results obtained in the Proctor test are insufficient. Since, for example, they do not provide information on the stress value which can produce particular soil compaction. Such information may be obtained with the use of the uniaxial soil compression test. Thus, it is justified to develop procedures that enable comparison of the results obtained in the Proctor and uniaxial test to counteract excessive soil compaction.

\section{Objective and scope of the paper and research methods}

The objective of the paper was to compare the results of soil material compaction made with the Proctor and uniaxial compression tests in order to search for relations between parameters of results of both methods to protect soil against excessive compaction with farming machine wheels. It was assumed that the analysis of the uniaxial unit stress value of the plate on the soil sample, obtained in the uniaxial test referred to soil moisture applied in the Proctor test and levels of its compaction that were obtained should be the basis for discussions.

Answers to the following questions were searched for:

1. What conditions are necessary (possible or impossible lateral expansion of soil) to deform soil in the uniaxial test to search for relations between the results of both tests?

2. Is it possible to determine the change of the soil compaction condition under the plate based on its movement with the use of the uniaxial test with possible lateral soil expansion?

3. Does the unit stress of the plate on the sample in the uniaxial compression test significantly depend on the soil moisture and its obtained compaction in the Proctor test?

While selecting material for research an assumption that was taken into consideration was that its properties should be variable mainly with regard to the textural group. Based on the analysis of information included in soil and agricultural maps and results of previous research (Błażejczak et al., 2010; Śnieg and Błażejczak 2017) fields of rural areas edges were selected for collecting the material: Nowy Przylep $(N P)$, Obojno $(O b)$ and Ostoja $(O s)$ - Nizina Szczecińska. Field investigations were carried out in layers which are at the depth of: $35-40,45-50$ and $55-60 \mathrm{~cm}$. Soil material in the form of loose mass was collected therefrom in order to determine typical soil properties, to carry out compaction in the Proctor apparatus and the uniaxial compression test. A textural group was determined with the 
Bouyoucosa-Casagrande method in Prószyński's modification. A pycnometer method was used for determination of the density of solid particles. The humus content was determined with Tiurin's method and soil reaction with the electrometrical method. The plastic limit was measured with the rolling method and the liquid limit with the use of the Cassagrande apparatus.

Soil material designated for the Proctor tests or uniaxial compression was sieved through a $6 \mathrm{~mm}$ screen. After sieving, material was divided into 8 portions moistened with a varied amount of water according to $\mathrm{PN}-88 / \mathrm{B}-04481$ and placed in a separate container. The amount of material for each container (moisture level) was selected so as to be sufficient for compression in the Proctor apparatus and forming 4 model samples which were then uniaxially compressed. Compaction in the Proctor apparatus was carried out with the use of a cylinder with the volume of $1000 \mathrm{~cm}^{3}$ with the unit compaction energy which was $0.59 \mathrm{~J} \cdot \mathrm{cm}^{-3}$ of soil. Forming of samples consisted in the initial soil compaction in steel rings (cylinders - figure 1a) to density lower by approx. $0.1 \mathrm{~g} \cdot \mathrm{cm}^{-3}$ than the minimum values reported in field conditions (Śnieg and Błażejczak, 2017). The internal diameter (D) and height of cylinders $(\mathrm{H})$ were respectively 100 and $30 \mathrm{~mm}$. Then, samples were subjected to the secondary uniaxial compaction with the speed of $50 \mathrm{~mm} \cdot \mathrm{min}^{-1}$ with an electric press with continuous registration of the stress made and sample deformation (figure 1b). Plates with diameters (d) of 50 or $98 \mathrm{~mm}$ were used in order to check the impact of the samples deformation conditions on the investigated relations between the tests. A principle was assumed that for basic tests which aim at the performance of the assumed objective of the paper, a plate will be applied, the use of which will cause achieving results that enable obtaining a regression equation with their higher evaluation.

a)

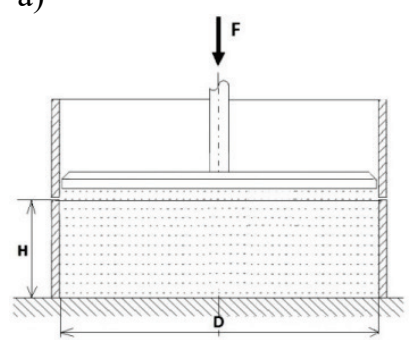

b)

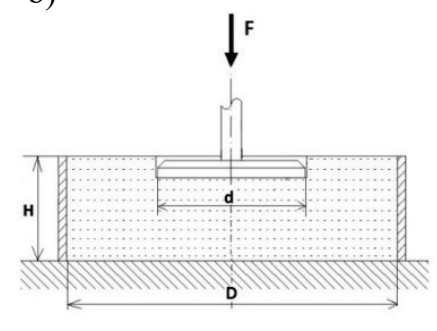

c)

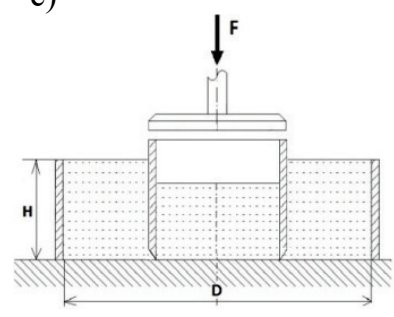

Figure 1. Stages of uniaxial compression test of samples: a) formation, b) uniaxial deformation, c) control of soil material compaction under the plate

Knowledge of the uniaxial test parameters and initial dry density of model samples enabled calculation of changes of dry density of solid particles under the plate under the unit stress on the sample. In case the plate $d 50$ was applied for deformation of the model samples, an assumption was made that compaction of the sample changes lineary along with the increase of the plate depth as in case of the plate $d 98$. Reasonableness of this assumption was verified by comparison of the dry density of solid particles calculated for the specific sample deformation with the measured ones with cylinders with the internal diameter of 50 $\mathrm{mm}$ (fig. 1c). In this case formed model samples were subjected to the secondary compac- 
Dariusz Błażejczak, Kinga Śnieg, Małgorzata Słowik

tion of samples to the maximum dry density obtained in the Proctor test which in relation to the object corresponded to deformation from 6 to approximately $8 \mathrm{~mm}$.

The obtained results of the Proctor test and uniaxial compression were used for construction of regression models for forecasting unit stress indispensable for production of compaction equal to the dry density obtained in the Proctor apparatus at the determined moisture.

\section{Results of research and their analysis}

Table 1 presents results of determination of own properties of the soil material. One may notice that soil material with the varied textural group was used. The highest content of fractions: sand, dust and loamy included material collected respectively from the following facilities: Ostoja $(O S)$, Nowy Przylep $(N P)$ and Obojno $(O b)$. Moreover, considerable differences between the facilities with regard to the humus content and values of reaction and relative moisture occurred. It was found out that the material came from compact soils difference between limits of liquidity and plasticity was higher than $1.0 \%$ moisture content

Table 1.

Average values of own properties of soils for the selected objects and measured layers

\begin{tabular}{|c|c|c|c|c|c|c|c|c|c|c|}
\hline \multirow{2}{*}{$\begin{array}{l}\frac{\overrightarrow{0}}{0} \\
\frac{0}{0}\end{array}$} & \multirow{2}{*}{ 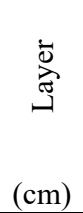 } & \multirow{2}{*}{$\begin{array}{c}\text { Textural } \\
\text { group acc. to } \\
\text { USDA (PTG } \\
2009)\end{array}$} & \multicolumn{3}{|c|}{$\begin{array}{l}\text { Fraction content } \\
\text { acc. to PTG (2009) }\end{array}$} & \multirow{2}{*}{$\begin{array}{l}\text { Specific } \\
\text { density }\end{array}$} & \multirow{2}{*}{$\begin{array}{c}\text { Reaction } \\
\text { (in } \mathrm{KCI} \text { ) } \\
(\mathrm{pH})\end{array}$} & \multirow{2}{*}{$\begin{array}{c}\text { Humus } \\
\text { content }\end{array}$} & \multirow{2}{*}{$\begin{array}{l}\text { Plastic } \\
\text { limit } \\
\\
\quad \% \text { v }\end{array}$} & \multirow{2}{*}{$\begin{array}{l}\text { Liquid } \\
\text { limit } \\
\text { (w) }\end{array}$} \\
\hline & & & Sand & $\begin{array}{l}\text { Silt } \\
(\%)\end{array}$ & Loam & & & & & \\
\hline \multirow{3}{*}{$N P$} & $35-40$ & $S L$ & 36.0 & 53.4 & 10.6 & 2.46 & 6.34 & 2.02 & 21.3 & 31.2 \\
\hline & $45-50$ & $S i L$ & 34.1 & 56.9 & 9.0 & 2.45 & 6.29 & 2.30 & 23.7 & 32.0 \\
\hline & $55-60$ & $L$ & 37.6 & 48.4 & 14.0 & 2.47 & 6.21 & 1.09 & 20.3 & 31.3 \\
\hline \multirow{3}{*}{$O b$} & $35-40$ & $L$ & 25.0 & 48.0 & 27.0 & 2.49 & 6.84 & 3.77 & 28.0 & 47.9 \\
\hline & $45-50$ & $S C L$ & 14.0 & 48.0 & 38.0 & 2.52 & 6.78 & 2.34 & 30.4 & 58.7 \\
\hline & $55-60$ & $S L$ & 12.0 & 46.0 & 42.0 & 2.40 & 6.52 & 1.70 & 31.4 & 73.0 \\
\hline \multirow{3}{*}{ Os } & $35-40$ & $L$ & 45.0 & 40.3 & 14.7 & 2.66 & 5.13 & 0.61 & 18.4 & 27.6 \\
\hline & $45-50$ & $L$ & 50.0 & 29.4 & 20.6 & 2.67 & 5.23 & 0.69 & 19.8 & 30.3 \\
\hline & $55-60$ & $L$ & 48.3 & 31.2 & 20.5 & 2.55 & 5.63 & 0.57 & 18.0 & 28.8 \\
\hline
\end{tabular}

According to the assumed course of the procedure, initially the impact of the manner of samples deformation on the searched relations between both tests was tested. It was proved that values of the unit stress $\left(P_{\mathrm{pdp}}\right)$ indispensable for production of compaction equal to dry density $\left(\rho_{\mathrm{dp}}\right)$ obtained in the Proctor apparatus in relation to the sample moisture $\left(w_{\mathrm{s}}\right)$ assume a varied course for applied plate diameters. The selected example for NP facility was presented in figure 2. Values of determination coefficient obtained for the plate with the diameter $d 50$ prove good adjustment of measurement points to regression lines $-R^{2} \geq 0.90$. In case of the plate with the diameter $d 98$, the coefficient of determination assumed consid- 
erably lower values $\left(R^{2} \leq 0.65\right)$ and measurement points are more scattered on the diagram. A different course of the regression line (fig. 2a) for applied plates may be justified with the phenomena that take place between the plate edge and the measuring cylinder wall which affected the recorded course of the unit stress from the value of sample deformation (Błażejczak, Dawidowski, 2016). Analysis of the diagram in figure $2 \mathrm{~b}$ shows that despite a similar trend in regression line value $P_{\text {pdp }}$ they are considerably higher than for the plate $d 98$. Similar results to those presented in figure 2 were obtained for facilities $O b$ and $O s$. But the smallest differences between values $R^{2}$ for plates $d 50$ and $d 98$ were reported for the facility $O s$. It might have resulted from the textural group of soil material with a considerably high content of sand (table 1) which considerably facilitates water and air filtration even with the use of a plate with a diameter close to the internal diameter of the cylinder. It should be emphasised that in each of the investigated cases values $P_{\text {pdp }}$ read for $d 98 \mathrm{~mm}$ assumed higher values for particular $w_{\mathrm{s}}$.

a)

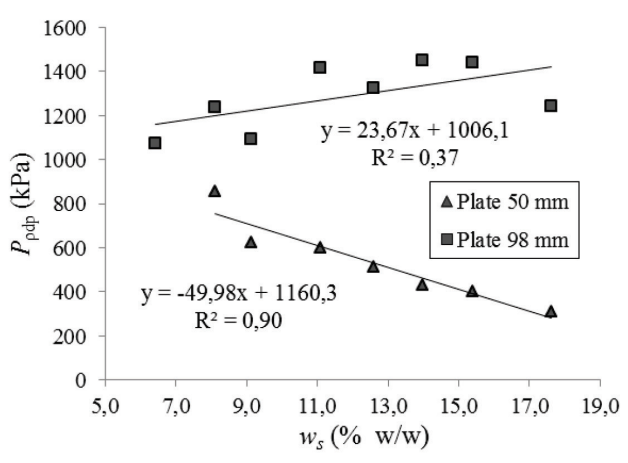

b)

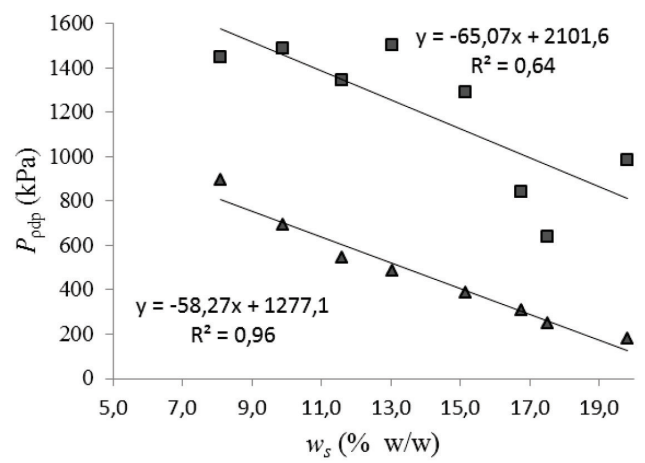

Figure 2. Values of the unit stress $\left(P_{\rho d p}\right)$ indispensable for production of equal compaction of dry density obtained in Proctor apparatus $\left(\rho_{d p}\right)$ for the plate diameters 50 or $98 \mathrm{~mm}$ in relation to the sample moisture $\left(w_{s}\right)$-facility $N P:$ a) layer $35-40 \mathrm{~cm}$, b) layer $45-50 \mathrm{~cm}$

Analysis of the unit stress value (P $\rho d p)$ presented in figure 2 enables a statement that in case of the plate with $98 \mathrm{~mm}$ diameter, they were considerably higher than the determined average unit stress on soil by wheels of agricultural vehicles and machine even for the heaviest vehicles used in field works (Walczyk, 1995; Jurga, 2009; Filipovic et al., 2016; Silva et al., 2016). For instance, unit stresses determined by Walczyk (1995) were at the maximum $300 \mathrm{kPa}$. On the other hand, the minimum value of the unit stress obtained in the conditions of the limited expansion of the sample exceeded $600 \mathrm{kPa}$ (fig. 2b). To conclude this part of research, one shall state that for the purposes of comparison of the unit compression tests with the soil compaction results in the Proctor apparatus in the context of testing the process of its compaction by agricultural tractors and machines, uniaxial deformation of samples should be carried out in conditions of their possible lateral expansion. It may also result from the fact that the uniaxial deformation in such conditions more reflects deformation in the Proctor apparatus and in the field conditions where soil compaction is 
Dariusz Błażejczak, Kinga Śnieg, Małgorzata Słowik

accompanied by moving soil masses outside the sphere of direct impact of wheels or working elements of agricultural machines and vehicles.

The research program was continued by soil material compaction in the Proctor apparatus and in the uniaxial sample deformation test with the use of a $50 \mathrm{~mm}$ plate, namely, under the conditions of possible lateral soil expansion.

Firstly, rightness of the assumption that compaction of the pressed sample changes linearly along with the increase of the plate depth was verified. Results of the comparison of the dry density of solid particles values calculated with the measured ones were presented in table 2. It was found out that these values did not differ significantly $-p>0.05$. In this case, lack of differences may be justified with a considerably low height of model samples $(H 30)$ and deformation value $(6.0-8.2 \mathrm{~mm})$ which resulted in the fact that relocation of soil particles outside a cylindrical area of direct effect of the plate was low. It should be added that distribution of stresses under the plate with a specific angle and relocation of particles requires formation of the compacted soil conic according to Terzaghy's theory (Błażejczak et al., 2017).

Table 2.

Results of comparison of values of measured and calculated dry density of solid particles of model samples after deformation

\begin{tabular}{|c|c|c|c|c|c|c|}
\hline \multirow{3}{*}{ Object } & \multirow{3}{*}{$\begin{array}{l}\text { Sample } \\
\text { moisture } \\
(\% \mathrm{w} / \mathrm{w})\end{array}$} & \multirow{3}{*}{$\begin{array}{c}\text { Initial dry } \\
\text { density of solid } \\
\text { particles } \\
\text { of a sample } \\
\left(\mathrm{g} \cdot \mathrm{cm}^{-3}\right)\end{array}$} & \multirow{3}{*}{$\begin{array}{c}\begin{array}{c}\text { Sample } \\
\text { deformation }\end{array} \\
(\mathrm{mm})\end{array}$} & \multicolumn{2}{|c|}{$\begin{array}{c}\text { Dry density of solid particles } \\
\text { after deformation }\end{array}$} & \multirow{3}{*}{$\begin{array}{c}\text { Value } \\
p p\end{array}$} \\
\hline & & & & calculated & measured & \\
\hline & & & & \multicolumn{2}{|c|}{$\left(\mathrm{g} \cdot \mathrm{cm}^{-3}\right)$} & \\
\hline$\overline{N P}$ & 18.1 & 1.28 & 8.0 & 1.68 & 1.71 & 0.234 \\
\hline$O b$ & 22.8 & 1.25 & 6.0 & 1.64 & 1.66 & 0.345 \\
\hline Os & 11.1 & 1.41 & 8.2 & 1.86 & 1.88 & 0.583 \\
\hline
\end{tabular}

Symbols: border probability $(\alpha=0.05)$

Output parameters and results of the Proctor and uniaxial compression tests were presented in table 3 . By analysis of the results within particular facilities one may notice that the minimum values of the unit stress on sample $\left(P_{\text {pdp }}\right)$ at which dry density of solid particles equal to the density obtained in the Proctor test $\left(\rho_{\mathrm{dp}}\right)$ were similar to the values of stress on soil by agricultural vehicles wheels (Walczyk, 1995; Jurga, 2009).

Multiple regression was firstly used for selection of equations for prediction of the unit stress $\left(P_{\text {pdp }}\right)$ necessary for production of compaction equal to the dry density of solid particles obtained in the Proctor test $\left(\rho_{\mathrm{dp}}\right)$ at specific moisture. By evaluation of independent variables of the obtained models it was found out that stress $P_{\text {pdp }}$ indispensable for production of $\rho_{\mathrm{dp}}$ does not significantly depend on this density $\left(\rho_{\mathrm{dp}}\right)$. Then, for selection of equations for forecasting $P_{\text {pdp }}$ linear regression was applied by using sample moisture $\left(w_{\mathrm{s}}\right)$ as an independent variable. The obtained equations were placed in table 4 . Models are highly significant $(\mathrm{p}<0.001)$ and well adjusted for measurement points - coefficient of determination $\left(r^{2}\right)$ was within 0.91 to 0.98 . 
Comparison of Proctor...

Table 3.

Output parameters and Proctor test results and unit compression of model samples with a plate of $50 \mathrm{~mm}$ diameter

\begin{tabular}{ccccccc}
\hline Object & $\begin{array}{c}\text { Layer } \\
(\mathrm{cm})\end{array}$ & $\begin{array}{c}w_{\mathrm{s}} \\
(\% \mathrm{w} / \mathrm{w})\end{array}$ & $\begin{array}{c}\rho_{\mathrm{dp}} \\
\left(\mathrm{g} \cdot \mathrm{cm}^{-3}\right)\end{array}$ & $\begin{array}{c}\rho_{\mathrm{dm}} \\
\left(\mathrm{g} \cdot \mathrm{cm}^{-3}\right)\end{array}$ & $\begin{array}{c}P_{\mathrm{m}} \\
(\mathrm{kPa})\end{array}$ & $\begin{array}{c}P_{\mathrm{pdp}} \\
(\mathrm{kPa})\end{array}$ \\
\hline \multirow{3}{*}{$N P$} & $35-40$ & $8.1-19.2$ & $1.58-1.74$ & $1.26-1.29$ & $55-364$ & $250-881$ \\
& $45-50$ & $9.9-19.8$ & $1.64-1.79$ & $1.25-1.28$ & $45-334$ & $173-688$ \\
& $55-60$ & $9.3-19.7$ & $1.65-1.79$ & $1.24-1.26$ & $29-280$ & $136-891$ \\
\hline \multirow{3}{*}{$\mathrm{Ob}$} & $35-40$ & $10.6-25.7$ & $1.49-1.64$ & $1.28-1.30$ & $91-384$ & $148-998$ \\
& $45-50$ & $15.7-32.0$ & $1.40-1.67$ & $1.25-1.28$ & $34-193$ & $75-778$ \\
& $55-60$ & $15.7-30.3$ & $1.41-1.65$ & $1.24-1.28$ & $30-294$ & $73-838$ \\
\hline \multirow{3}{*}{$O s$} & $35-40$ & $8.7-18.2$ & $1.74-1.89$ & $1.48-1.52$ & $99-407$ & $148-1194$ \\
& $45-50$ & $9.9-19.7$ & $1.67-1.78$ & $1.44-1.48$ & $128-559$ & $201-1433$ \\
& $55-60$ & $11.3-21.3$ & $1.59-1.84$ & $1.43-1.46$ & $68-388$ & $83-1031$ \\
\hline
\end{tabular}

Symbols $w_{\mathrm{s}}-$ material moisture during Proctor test and uniaxial compression test, $\rho_{\mathrm{dp}}-$ dry density of solid particles obtained in Proctor test, $\rho_{\mathrm{dm}}-$ dry density of solid particles of model samples (after formation), $P_{\mathrm{m}}-$ formation stress of model samples, $P_{\mathrm{pdp}}$ - unit stress on a sample at which density equal to the dry density result obtained in Proctor test was obtained $\left(\rho_{\mathrm{dp}}\right)$

Table 4.

Regression equations for forecasting unit stress $\left(P_{\rho d p}\right)$ indispensable for production of compaction equal to dry density $\left(\rho_{d p}\right)$ obtained in Proctor apparatus and their statistical evaluation

\begin{tabular}{lcccc}
\hline Object & $\begin{array}{c}\text { Layer } \\
(\mathrm{cm})\end{array}$ & Equation & \multicolumn{2}{c}{ Statistical assessment of equation } \\
\cline { 3 - 5 } & $35-40$ & $P_{\rho d p}=-40.2 w_{\mathrm{s}}+1023.8$ & $<$ & $r^{2}$ \\
\hline$N P$ & $45-50$ & $P_{\rho d p}=-49.2 w_{\mathrm{s}}+1151.0$ & $<0.0001$ & 0.98 \\
$N P$ & $55-60$ & $P_{\rho d p}=-53.3 w_{\mathrm{s}}+1238.6$ & $<0.0001$ & 0.96 \\
$N P$ & $35-40$ & $P_{\rho d p}=-62.7 w_{\mathrm{s}}+1780.1$ & $<0.0001$ & 0.98 \\
\hline$O b$ & $45-50$ & $P_{\rho d p}=-55.2 w_{\mathrm{s}}+1626.2$ & $<0.0001$ & 0.98 \\
$O b$ & $55-60$ & $P_{\rho d p}=-48.6 w_{\mathrm{s}}+1533.0$ & $<0.0001$ & 0.95 \\
$O b$ & $35-40$ & $P_{\rho d p}=-124.4 w_{\mathrm{s}}+2375.4$ & $<0.0001$ & 0.98 \\
\hline$S$ & $45-50$ & $P_{\rho d p}=-127.1 w_{\mathrm{s}}+2689.2$ & $<0.0001$ & 0.98 \\
$O s$ & $55-60$ & $P_{\rho d p}=-92.2 w_{\mathrm{s}}+1972.9$ & $<0.0001$ & 0.95 \\
$O s$ &
\end{tabular}

Symbols: $w_{\mathrm{s}}-$ soil sample moisture, $p$ - significance level $(\alpha=0.05), r^{2}-$ coefficient of linear regression determination

Equations of regression (table 4) were obtained on the produced model samples with uniform initial dry density $\left(\rho_{\mathrm{dm}}\right)$ - distribution of values for particular layers did not exceed $0.05 \mathrm{~g} \cdot \mathrm{cm}^{-3}$ (table 3 ). In field conditions, dry density of solid particles changes as a result of the impact of both natural and anthropological factors. Thus, further research should verify the impact of the initial density of the sample on the forecasted value of the unit stress indispensable for production of the specific soil density state. 


\section{Conclusions}

1. For the purposes of comparison of the unit compression tests with the soil compaction results in the Proctor apparatus in the context of testing the process of its compaction by agricultural tractors and machines, uniaxial deformation of samples should be carried out in conditions of their possible lateral expansion

2. In case of model samples with diameter of 100 and height of $30 \mathrm{~mm}$ using uniaxial test with possible lateral soil expansion value of the plate movement may be used for determination of the obtained compaction.

3. Value of the unit stress on the soil sample in the uniaxial stress test that enables obtaining dry density of solid particles obtained in the Proctor apparatus significantly depends on the sample moisture.

\section{References}

Aragón, A., García, M.G. , Filgueira, R.R. , Pachepsky, Ya.A. (2000). Maximum compactibility of Argentine soils from the Proctor test, The relationship with organic carbon and water content. Soil\&Tillage Research, 56, 197-204.

Błażejczak, D. (2010). Prognozowanie naprężenia granicznego $w$ warstwie podornej gleb ugniatanych kołami pojazdów rolniczych. Wyd. ZUT w Szczecinie. ISBN 978-83-7663-050-2.

Błażejczak, D., Dawidowski, J.B. (2013). Problem wykorzystania gęstości objętościowej gleby w ocenie jej zagęszczenia. Journal of Research and Applications in Agricultural Engineering, $58(1), 17-20$.

Błażejczak, D., Dawidowski, J.B. (2016). The impact of the plate diameter on the determined value of pre-compaction stress of samples made of silt soil. Agricultural Engineering, Vol. 20, No 2, 5-14.

Błażejczak, D., Nowowiejski R., Dawidowski J.B. (2017). Impact of friction on the uniaxial soil sample copression proces. Agricultural Engineering, Vol. 21, No 2, 101-112.

Hakansson, I., Lipiec, J. (2000). A revive of the usefulness of relative bulk density values in studies of soil structure and compaction. Soil \& Tillage Research, 53, 71-85.

Jurga, J. (2009). The verification of mathematical model designed to determining the area of the contact surface as well as unit pressure exerted onto soil by wheels of the agricultural vehicles. Journal of Research and Applications in Agricultural Engineering, 54(1), 83-88.

Krasowicz S., Oleszek, W., Horabik, J., Dębicki, R., Jankowiak, J., Stuczyński, T., Jadczyszyn, J. (2011). Racjonalne gospodarowanie środowiskiem glebowym Polski. Polish Journal of Agrono$m y, 7,43-58$.

Kumar, D., Bansal, M. L., Phogat, V. K. (2009). Compactability in relation to texture and organic matter content of alluvial soils. Indian Journal of Agricultural Research, 43(3), 180-186.

Nhantumbo, A. B. J. C. , Cambule, A. H. (2006). Bulk density by Proctor test as a function of texture for agricultural soils in Maputo province of Mozambique. Soil\&Tillage Res. 87, 231-239.

Polskie Towarzystwo Gleboznawcze (2009). Klasyfikacja uziarnienia gleb i utworów mineralnych PTG 2008. Roczniki Gleboznawcze, 60(2), 5-16.

PN-88/B-04481 (1988). Grunty budowlane. Badania próbek gruntu.

Szeptycki, A. (2003). Wpływ ciężkich maszyn rolniczych na fizykomechaniczne właściwości gleby. Journal of Research and Application in Agricultural Engineering, 48(3), 5-9.

Śnieg, K., Błażejczak, D. (2017). Evaluation of subsoil compaction of plastic soils. Agricultural Engineering, Vol 21, No 1, pp. 85-94.

Tarkiewicz, S., Nosalewicz, A. (2005). Effect of organic carbon content on the compactibility and penetration resistance of two soils formed from loess. International Agrophysics, 19, 345-350. 
Comparison of Proctor...

Van den Akker, J. J. H., Arvidsson, J., Horn, R. (2003). Introduction to the special issue on experiences with the impact and prevention of subsoil compaction in the European Union. Soil\&Tillage Research, 73, 1-8.

Wagner, L. E., Ambe, N. M., Ding, D. (1994). Estimating a Proctor Density Curve from Intrinsic Soil Properties. Transactions of the ASAE, Vol. 37(4), 1121-1125.

Walczyk, M. (1995). Wybrane techniczne i technologiczne aspekty ugniatania gleb rolniczych agregatami ciagnikowymi. Zeszyty Naukowe Akademii Rolniczej w Krakowie, Rozpr. 202, ISSN $1233-4189$.

\section{PORÓWNANIE TESTÓW PROCTORA \\ I JEDNOOSIOWEGO ŚCISKANIA DLA WYBRANYCH GLEB}

Streszczenie. Celem pracy było porównanie rezultatów zagęszczania materiału glebowego prowadzonego za pomocą testów Proctora i jednoosiowego ściskania, ukierunkowane na poszukiwanie zależności pomiędzy tymi metodami. $Z$ warstwy leżącej na głębokości od $35 \mathrm{do} 60 \mathrm{~cm}$ pobrano materiał glebowy w postaci luźnej masy celem oznaczenia jego typowych cech własnych (skład granulometryczny, gęstość fazy stałej, zawartość próchnicy, odczyn, granice plastyczności i płynności) i przeprowadzenia jego zagęszczania $\mathrm{w}$ aparacie Proctora oraz $\mathrm{w}$ teście jednoosiowego ściskania. Wyniki obu testów wykorzystano do budowy modeli regresji odwzorowujących przebieg nacisku jednostkowego $\left(P_{\rho d p}\right)$, niezbędnego do wytworzenia zagęszczenia równoważnego gęstości objętościowej uzyskiwanej w aparacie Proctora $\left(\rho_{\mathrm{dp}}\right)$, w zależności od wilgotności próbki $\left(w_{\mathrm{s}}\right)$. Stwierdzono, że wartość nacisku $P_{\rho d p}$ wywieranego na próbkę gleby w teście jednoosiowego ściskania zależy istotnie od $w_{\mathrm{s}}$. Wykazano, że do celów porównywania wyników obu testów jednoosiowe odkształcanie próbek należy wykonywać w warunkach możliwej ich bocznej rozszerzalności. Wykazano także, że stosując test jednoosiowy z możliwą boczną rozszerzalnością gleby, z zastosowaniem próbek modelowych o średnicy 100 i wysokości $30 \mathrm{~mm}$, można do określenia uzyskiwanego zagęszczenia wykorzystać wartość przemieszczenia stempla.

Slowa kluczowe: gleba, zagęszczanie, test Proctora, test jednoosiowy 